\title{
Regional monitoring of the urinary tract infections etiological spectrum pathogens in the child population in Chernivtsi region: dynamic changes, age, gender, administrative and territorial characteristics
}

\author{
V. V. Bezruk, T. 0. Bezruk, O. R. Babiy, S. 0. Sokolnyk, M. I. Sheremet, \\ V. V. Maksymyuk, O. I. Godovanets, O. S. Godovanets, A. I. Kovtun \\ Higher State Educational Establishment of Ukraine “Bukovinian State Medical University”, Chernivtsi, Ukraine
}

Microbiological monitoring of the uropathogens is an effective "tool" for urinary tract infectious and inflammatory diseases treatment quality improvement.

The aim of the article is to determine the range of the urinary tract infectious-inflammatory diseases etiological spectrum groups of pathogens in the child population in Chernivtsi region.

Materials and methods. The etiologic spectrum of uropathogens identified in the urine samples of 657 patients who were provided with a specialized medical care in the Nephrology Department of the "Municipal Children's Clinical Hospital", Chernivtsi (2014-2015) was analyzed in order to dynamically control the possible changes of the "urinary tract infections" (UTI) regional etiological structure and antibiotic resistance of pathogens; identification of age and gender differences of urine microbial diversity in the child population in Chernivtsi region (2014-2015) compared with the monitoring data for the 2009-2013 period.

Results. A significant difference has been found in the etiological structure of the urine microbial diversity in children with infectious and inflammatory diseases of the urinary tract (Gram-positive cocci $-p<0.05$; Enterobacteria $-p<0.01$; resident microflora $p<0.01)$ in comparison with uropathogens extracted in children with urinary tract noninfectious diseases. Administrative and territorial differences have been registered in etiological structure of the urine microbial diversity in children living in the urban areas $(p<0.01)$ from their peers living in the rural areas.

Conclusions. The regional monitoring data showed changes of the urine resident microflora $(p<0.01)$ without significant changes of etiological spectrum of the UTI pathogens in examined children ( $0-18$ years old) with urinary tract infectious and inflammatory diseases during 2009-2015 in Chernivtsi region. At the same time it as a matter of concern a significant increase in the proportion of "negative results" (no growth) in the urine bacteriological analysis $(p<0.01)$, which might indirectly indicate the "uncontrolled" use of antibiotics among children in the region.

\section{Регіональний моніторинг етіологічного спектра збудників інфекцій сечової системи серед дитячого населення Чернівецької області: динамічні зміни, вікові, гендерні та адміністративно-територіальні особливості}

В. В. Безрук, Т. О. Безрук, О. Р. Бабій, С. О. Сокольник, М. І. Шеремет,

В. В. Максим'юк, О. І. Годованець, О. С. Годованець, А. І. Ковтун

Мікробіологічний моніторинг уропатогенів - дієвий «інструмент» у підвищенні якості лікування інфекційно-запальних захворювань сечової системи.

Мета роботи - встановити динаміку етіологічного спектра груп збудників інфекційно-запальних захворювань сечової системи в дитячого населення Чернівецької області.

Матеріали та методи. Здійснили аналіз етіологічного спектра уропатогенів, що ідентифіковані у 657 зразках сечі пацієнтів, яким надавалась спеціалізована медична допомога в нефрологічному відділенні КМУ «Міська дитяча клінічна лікарня» м. Чернівці (2014-2015рр.), з метою динамічного контролю щодо можливих змін у регіональній етіологічній структурі груп збудників «інфекцій сечової системи» (ICC); виявлення вікових і гендерних відмінностей мікробного «пейзажу» сечі в дитячого населення Чернівецької області (2014-2015рр.) у порівнянні з отриманими даними моніторингу за період 2009-2013 років.

Результати. Виявлена вірогідна різниця в етіологічній структурі мікробного «пейзажу» сечі в пацієнтів дитячого віку з інфекційно-запальними захворюваннями сечовидільної системи (грампозитивні коки - $p<0,05$; ентеробактерії $p<0,01$; резидентна мікрофрлора - $p<0,01)$ порівняно з виділеними уропатогенами при неінфекційних захворюваннях сечовидільної системи дітей. Зареєстровані адміністративно-територіальні відмінності в етіологічній структурі мікробного «пейзажу» сечі в пацієнтів дитячого віку - мешканців міських населених пунктів $(p<0,01)$ від їхніх однолітків, які проживають у сільській місцевості.

Висновки. Дані регіонального моніторингу показали: протягом 2009-2015 рр. спостереження серед дітей (0-18 років) Чернівецької області з інфекційно-запальними захворюваннями сечовидільної системи відбулись зміни у резидентній мікрофрлорі сечі $(p<0,01)$ без суттєвих змін в етіологічному спектрі штамів збудників ICC. Водночас викликає занепокоєння вірогідне збільшення частки «негативних результатів» (відсутній ріст) у бактеріологічних дослідженнях сечі $(p<0,01)$, що опосередковано може свідчити про «неконтрольоване» застосування антибактеріальних препаратів серед дитячого населення регіону. 
Ключевые слова: инфекция мочевой системы, Аети.

\section{Запорожский} медицинский журнал. - 2017. T. 19, № 5(104). C. $647-651$

\title{
Региональный мониторинг этиологического спектра возбудителей инфекций мочевой системы среди детского населения Черновицкой области: динамические изменения, возрастные, гендерные и административно- территориальные особенности
}

\author{
В. В. Безрук, Т. А. Безрук, Е. Р. Бабий, С. А. Сокольник, М. И. Шеремет, \\ В. В. Максимюк, О. И. Годованец, А. С. Годованец, А. И. Ковтун
}

Микробиологический мониторинг уропатогенов является действенным «инструментом» в повышении качества лечения инфекционно-воспалительных заболеваний мочевой системы.

Цель работы - установить динамику этиологического спектра групп возбудителей инфекционно-воспалительных заболеваний мочевой системы у детского населения Черновицкой области.

Материалы и методы. Проведён анализ этиологического спектра уропатогенов, идентифицированных в 657 образцах мочи пациентов, которым оказывалась специализированная медицинская помощь в нефрологическом отделении КГУ «Городская детская клиническая больница» г. Черновцы (2014-2015 гг.) с целью динамического контроля региональной этиологической структуры групп возбудителей «инфекций мочевой системы» (ИМС); выявления возрастных и гендерных различий микробного «пейзажа» мочи детского населения Черновицкой области (2014-2015 гг.) в сравнении с полученными ранее данными мониторинга за период 2009-2013 гг.

Результаты. Выявлены достоверные отличия в этиологической структуре уропатогенов, выделенных в моче пациентов с инфекционно-воспалительными заболеваниями мочевыделительной системы (грамположительные кокки - $p<0,05$; энтеробактерии - $p<0,01$; резидентная микрофрлора $-p<0,01$ ) в сравнении с уропатогенами при неинфекционных заболеваниях мочевыделительной системы детей. Зарегистрированы административно-территориальные отличия в этиологической структуре микробного «пейзажа» мочи у пациентов детского возраста - жителей городских населённых пунктов ( $<<0,01)$ от их сверстников, проживающих в сельской местности.

Выводы. Данные регионального мониторинга показали, что в течение 2009-2015 гг. наблюдения среди детского населения (0-18 лет) Черновицкой области с инфекционно-воспалительными заболеваниями мочевыделительной системы произошли изменения в резидентной микрофллоре мочи $(p<0,01)$ без существенных изменений в этиологическом спектре штаммов возбудителей ИМС. В то же время вызывает беспокойство достоверное увеличение доли «отрицательных результатов» (отсутствует рост) в бактериологических исследованиях мочи ( $<<0,01)$, что косвенно может свидетельствовать о «неконтролируемом» применении антибактериальных препаратов среди детского населения региона.

\section{Introduction}

Infections of the urinary system (UTI) among children are a global medical and social problem; data of etiologic spectrum of children's uropathogens in Ukraine differ, and it shows a need to study their regional characteristics [1-5].

\section{Purpose}

The aim of the article is to determine the range of etiological spectrum groups of the urinary tract infectious-inflammatory diseases causative agents in the child population in Chernivtsi region.

\section{Materials and methods}

The etiologic spectrum of uropathogens identified in the urine samples of 657 patients who were provided with a specialized medical care in the Nephrology Department of the "Municipal Children's Clinical Hospital", Chernivtsi (2014-2015) was analyzed: there were 191 (29.07\%) boys and 466 $(70.93 \%)$ girls; children under the age of three years -241 (36.68 \%), 4-6 years old children - 123 (18.72\%), 7-14

Table 1. Distribution of primary examined children with urinary system diseases

\begin{tabular}{llll}
\hline Groups of examined patients & \multirow{2}{*}{$\begin{array}{l}\text { The total } \\
\text { number, } \mathbf{n}\end{array}$} & \multicolumn{2}{l}{ Primarily examined } \\
\cline { 3 - 4 } & & Abs., $\mathbf{n}$ & $\%$ \\
\hline Infectious-inflammatory diseases of the urinary system & 482 & 330 & 68.46 \\
Non-infectious diseases of the urinary system & 175 & 115 & 65.71 \\
Total & 657 & 445 & 67.73 \\
\hline
\end{tabular}

years old children - $183(27.86 \%)$ and $15-18$ years old children - $110(16.74 \%)$.

To the main group of examined children $(n=482)$ included patients with urinary system infectious-inflammatory diseases, which were diagnosed according to ICD-10 № 10-11.1 Among kidney infections were: Acute tubulointerstitial № 10 (tubulo-interstitial) nephritis; Chronic tubulointerstitial № 11 (tubulo-interstitial) nephritis; № 11.1 Chronic obstructive pyelonephritis; № 30.0 Acute cystitis; № 30.1 Chronic cystitis.

The comparison group $(n=175)$ included patients with non-infectious diseases of the urinary system with nosology code according to ICD-10: N00 Acute nephrotic syndrome; № 03 Chronic nephrotic syndrome; № 04 Nephrotic syndrome; № 15 Other kidney tubulo-interstitial diseases; № 18 Chronic kidney failure; № 39 Other disorders of the urinary system; № 39.2 Orthostatic proteinuria which is not specified; R30 Pain associated with urination; R30.1 Tenesmus of the urinary bladder; R32 Urinary incontinence which is not specified.

It should be noted that the results of both groups primary examination were selected for statistical analysis and further analysis of the data (Table 1).

Bacteriological investigation of urine samples was made at the State Establishment "L. I. Medved's Research Center of Preventive Toxicology, Food and Chemical Safety, Ministry of Health of Ukraine", Kyiv. Gender and specific identification of selected pathogens was generally carried out using clinical microbiology methods. It has been found that etiologically significant pathogens were such pathogens amount of which in $1 \mathrm{ml}$ of urine was higher or close to 


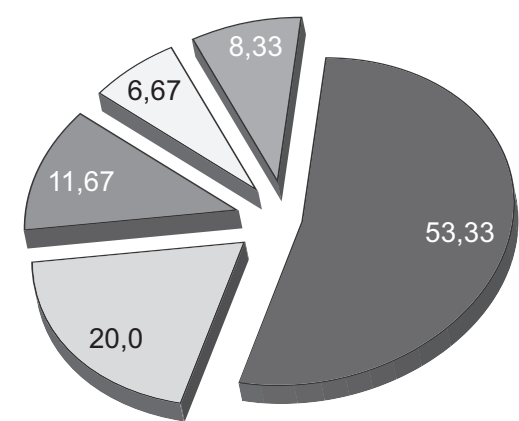

1

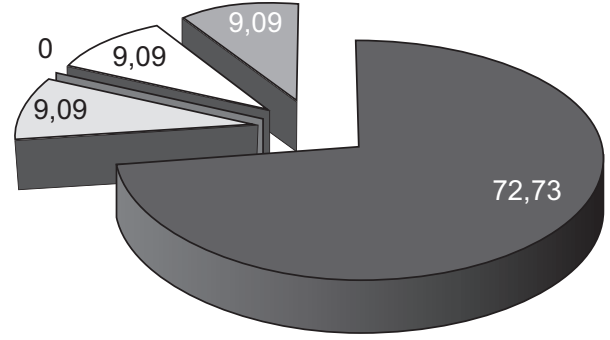

$\square$ Enterobacteriaceae (except Ptroteus mirabilis)

$\square$ Ptroteus mirabilis

$\square$ Gram-negative nonfermentical bacteria

$\square$ Gram-positive cocci

$\square$ Fungi

Fig. 1. Etiological diversity of strains (\%) which were taken from the examined patients ( 1 - infectious-inflammatory diseases of the urinary system; 2 - non-infectious diseases of the urinary system).

$1 \times 10^{3}$ of colony-forming units in the case of enterobacteria excretion. They were put to etiology significant units during the excretion of pseudomonas, staphylococcus aureus and fungi yeast if their number in $1 \mathrm{ml}$ of urine was less than $1 \times 10^{2}$ of colony-forming units. Pathogens' antibiotic susceptibility was determined according to the order of Ministry of Health of Ukraine № 167 from the $5^{\text {th }}$ of April, 2007 “On approving the methodological guidelines "Determination of the sensitivity of microorganisms to antibiotics"'”.

With the purpose of the dynamic control of possible changes in the regional etiological structure and antibiotic resistance of pathogens that cause the "urinary tract infections" (UTI); the age and gender differences of urine microbial diversity in the child population in Chernivtsi region (2014-2015) compared with the monitoring data for the 2009-2013 period were identified.

Statistical analysis of the results - an assessment of the results using the Fisher's angular transformation method; difference in frequency among the groups was assessed using the Pearson square calculation method $\left(\mathrm{c}^{2}\right)[6]$.

\section{Results and discussion}

Etiological range of strains from the urine of patients was consisted of Enterobacteriaceae family traces (E.coli, K. pneumoniae, $P$. mirabilis, $P$. rettgery), Gram-negative nonfermenting bacteria (genera Pseudomonas and Alcaligenes); staphylococci (S. aureus, S. epidermidis), enterococci (E. faecalis), streptococci (S. pyogenes), yeast fungi (C. albicans) (Fig. 1).

The percentage of etiologically significant microorganisms detection from urine of patients with UTI was similar in both sexes of the examined children, only teenage girls were marked with growing of this indicator, it was higher than at boys more than 3 times.

The analysis of uropatogens etiologic spectrum has shown significant differences in the microbial diversity of both examined groups urine - the main group and the group of comparison (Table 2).

The analysis of nosological forms microbial diversity hasn't revealed significant differences in the structure of detected strains in the main group of examined patients with UTI (Fig. 2)

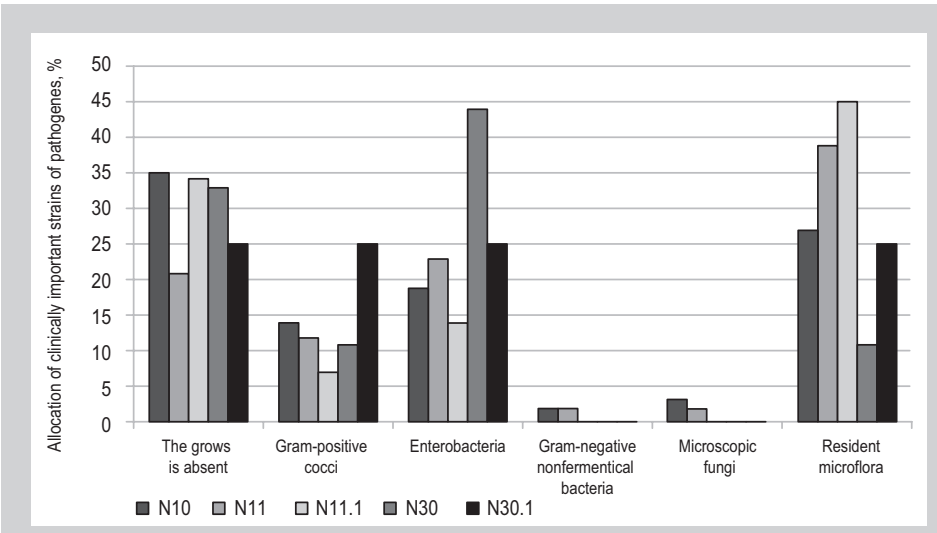

Fig. 2. Microbial diversity of urine in the examined patients with infectious-inflammatory diseases of the urinary system.

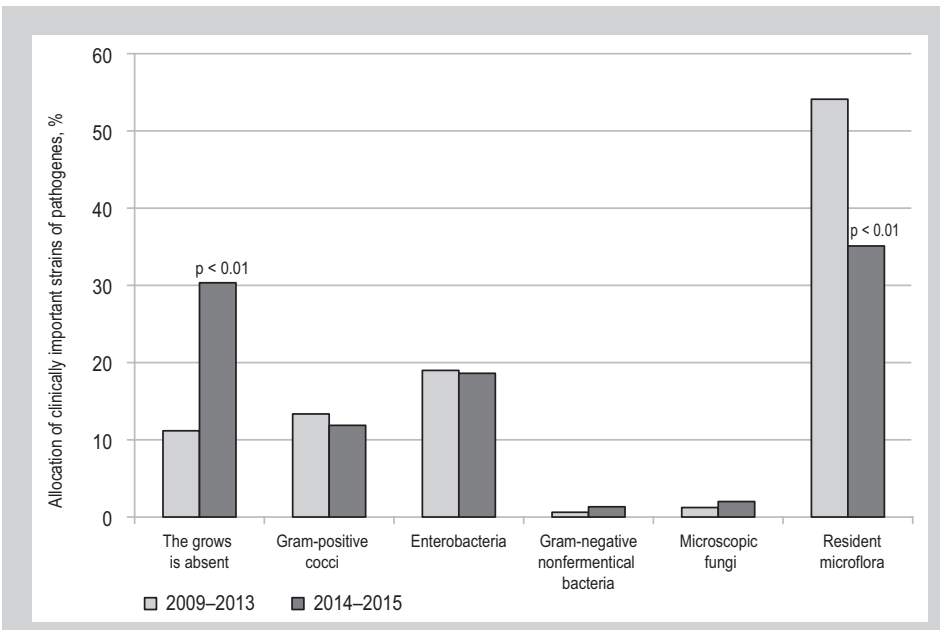

Fig. 3. Dynamic changes in microbial diversity of the child population urine in Chernivtsi region during 2009-2015.

Administrative and territorial differences in etiological structure of urine microbial diversity in pediatric patients have been registered - residents of urban areas $(p<0.01)$ from their rural areas peers (Table 3).

The regional monitoring data showed that the observation 
Table 2. Structure of uropatogens etiological spectrum in the examined patients with the urinary system diseases

\begin{tabular}{|c|c|c|c|c|c|}
\hline \multirow[t]{2}{*}{ Structure of etiological spectrum of uropatogens } & \multicolumn{2}{|c|}{ The main group $(n=482)$} & \multicolumn{2}{|c|}{ The group of comparison $(n=175)$} & \multirow[t]{2}{*}{ p } \\
\hline & Abs., $n$ & $\%$ & Abs., $n$ & $\%$ & \\
\hline The growth is absent & 183 & $37 \%$ & 22 & $13 \%$ & $p<0.01$ \\
\hline Gram-positive cocci & 75 & $15 \%$ & 14 & $8 \%$ & $p<0.05$ \\
\hline Enterobacteria & 125 & $25 \%$ & 8 & $5 \%$ & $p<0.01$ \\
\hline Gram-negative nonfermenting bacteria & 7 & $2 \%$ & 5 & $2 \%$ & - \\
\hline Microscopic fungi & 11 & $2 \%$ & 6 & $3 \%$ & - \\
\hline
\end{tabular}

Table 3. Administrative-territorial differences in the etiological structure of uropatogens among the examined children with diseases of the urinary system

\begin{tabular}{|c|c|c|c|c|c|c|c|}
\hline \multirow{2}{*}{$\begin{array}{l}\text { Structure of etiological spectrum } \\
\text { of uropatogens }\end{array}$} & \multicolumn{2}{|c|}{ Residents of the regional subordination } & \multicolumn{2}{|c|}{ Residents of the district subordination } & \multicolumn{2}{|c|}{ Residents of rural areas } & \multirow[t]{2}{*}{$p$} \\
\hline & Abs., $n$ & $\%$ & Abs., $n$ & $\%$ & Abs., $n$ & $\%$ & \\
\hline The growth is absent & 99 & $32 \%$ & 13 & $34 \%$ & 95 & $27 \%$ & - \\
\hline Gram-positive cocci & 39 & $13 \%$ & 6 & $16 \%$ & 44 & $13 \%$ & - \\
\hline Enterobacteria & 71 & $23 \%$ & 7 & $18 \%$ & 61 & $17 \%$ & - \\
\hline Gram-negative nonfermenting bacteria & 4 & $1 \%$ & 1 & $3 \%$ & 7 & $2 \%$ & - \\
\hline Microscopic fungi & 10 & $3 \%$ & 1 & $3 \%$ & 6 & $2 \%$ & - \\
\hline
\end{tabular}

of children (0-18 years old) in Chernivtsi region with infectiousinflammatory diseases of the urinary tract during 2009-2015 had been characterized by a change in the resident microflora of the urine $(p<0.01)$ without significant changes of the UTI strains etiological spectrum. At the same time a significant increase in the proportion of "negative results" (no growth) in the urine bacteriological analysis $(p<0.01)$ was traced, which might indirectly indicate the "uncontrolled" use of antibiotics among children in the area (Fig. 3).

\section{Conclusions}

1. During the urinary tract infections among child population in Chernivtsi region the leading etiological causative agent was the strain of Enterobacteriaceae family (except Proteus mirabilis). A significant difference has been found in the etiological structure of microbial diversity in children's with infectious and in-flammatory diseases of the urinary tract urine (Gram-positive cocci $-p<0.05$; enterobacteria $-p<0.01$; resident microflora $-p<0.01$ ) in comparison with ex-tracted uropathogens in urinary tract noninfectious diseases in children of the region.

2. The percentage of urine etiology meaningful microflora excretion in pa-tients with UTI was generally similar in children of both sexes, except for adoles-cent girls - the frequency of uropatogens excretion was 3 times more $(p<0.05)$ compared to peers.

3. Administrative and territorial differences have been registered in etiolog-ical structure of the urine microbial diversity in children living in the urban areas $(p<0.01)$ from their peers living in the rural areas

The perspectives of further scientific research are the dynamics of uropatogens antibiotic resistance analysis among pediatric patients in Chernivtsi region; dynamic control of regional microbiological monitoring among child population in this region.

\section{References}

[1] Bezruk, V., Blinder, O., Bezruk, T., Blinder, O., \& Yurniuk, S. (2014) Etiological structure of the urinary system infections, its dynamic, dependence on patients sex and relation with resident urine microflora among inhabitants of Chernivtsi region and town of Chernivtsi. Canadian Scientific Journal, 2, 25-35.

[2] Bezruk, V. V. (2015). Infektsii sechovoii systemy u ditei: etiolohichna struktura, vikovi ta henderni osoblyvosti [Urinary tract infection in children: etiological structure, age and gender characteristics]. Zdorov'e rebenka, 7, 113-117. [in Ukrainian].

[3] Bezruk, V. V., Blinder, O. V., Bezruk, T. O., Blinder, O. O., \& Deyneka, S. E. (2015). Antybiotykorezystentnist osnovnykh hrup zbudnykiv infektsii sechovoi systemy [Antimicrobial resistance in pathogens causing urinary tract infections]. Ukrainskyi zhurnal nefrolohii ta dializu, 4, 9-15. [in Ukrainian].

[4] Grabe, M., Bjerklund-Johansen, T. E., Botto, H., Çek, M., Naber, K. G., Pickard, R. S., et al. (2013) Guidelines on urological infections. Eur Assoc Urology.

[5] Stein, R., Dogan, H. S., Hoebeke, P., Kočvara, R., Nijman, R. J., Radmayr, C., et al. (2015) Urinary Tract Infections in Children: EAU/ ESPU Guidelines. European urology, 67(3), 546-558. doi: 10.1016/j. eururo.2014.11.007.

[6] Rosner, B. (2010) Fundamentals of Biostatistics. Duxbury Press.

\section{Information about authors:}

Bezruk V. V., MD, PhD, Associate Professor, Department of Pediatrics, Neonatology and Perinatology, Higher State Educational Establishment of Ukraine "Bukovinian State Medical University", Chernivtsi, Ukraine.

Researcher ID: B-8621-2017

Bezruk T. 0., MD, PhD, Associate Professor,

Department of Internal Medicine, Higher State Educational Establishment of Ukraine "Bukovinian State Medical University", Chernivtsi, Ukraine.

Researcher ID: c-9965-2017

Babiy O. R., Teacher, Department of Foreign Languages, Higher State Educational Establishment of Ukraine "Bukovinian State Medical University", Chernivtsi, Ukraine.

Researcher ID: D-4132-2017

Sokolnyk S. O., MD, PhD, DSci, Associate Professor, Department of Pediatric Surgery and Otolaryngology, Higher State Educational Establishment of Ukraine "Bukovinian State Medical University", Chernivtsi, Ukraine.

Researcher ID: B-9306-2017

Sheremet M. I., MD, PhD, Associated Professor, Surgery Department №1, Higher State Educational Establishment of Ukraine "Bukovinian State Medical University", Chernivtsi, Ukraine.

Researcher ID: B-4388-2017

Maksymyuk V. V., MD, PhD, DSci, Professor, Surgery Department №1, Higher State Educational Establishment of Ukraine "Bukovinian State Medical University", Chernivtsi, Ukraine. Researcher ID: B-5128-2017 
Godovanets 0. I., MD, PhD DSci, Associate Professor, Department of Surgical and Pediatric Stomatology, Higher State Educational Establishment of Ukraine "Bukovinian State Medical University", Chernivtsi, Ukraine.

Researcher ID: B-7111-2017,

Godovanets O. S., MD, PhD, Assistant, Department of Pediatrics, Neonatology and Perinatology, Higher State Educational

Establishment of Ukraine "Bukovinian State Medical University", Chernivtsi, Ukraine.

Researcher ID: B-1224-2017

Kovtun A. I., MD, PhD, Associate Professor, Department

of Anesthesiology and Reanimatology, Higher State Educational

Establishment of Ukraine "Bukovinian State Medical University",

Chernivtsi, Ukraine.

Researcher ID: C-8245-2017

\section{Відомості про авторів:}

Безрук В. В., канА. меА. наук, Аоцент каф. пеАіатрії, неонатології та перинатальної медицини,

ВАНЗ “Буковинський Аержавний меАичний університет”, м. Чернівці, Україна.

Безрук Т. О., канА. меА. наук, Аоцент каф. внутрішньої меАицини та інфекційних хвороб, ВАНЗ “Буковинський Аержавний медичний університет”, м. Чернівці, україна.

Бабій О. Р., викладач каф. іноземної мови,

BAНЗ “Буковинський Аержавний медичний університет”, м. Чернівці, Україна.

Сокольник С. О., А-р меА. наук, Аоцент каф. Аитячої хірургії та отоларингології, ВАНЗ України “Буковинський Аержавний медичний університет”, м. Чернівці, Україна.

Шеремет М. І., канА. меА. наук, Аоцент каф. хірургії № 1 , BАНЗ “Буковинський Аержавний медичний університет”, м. Чернівці, Україна.

Максим'юк В. В., А-р меА. наук, професор каф. хірургії № 1 ,

ВАНЗ “Буковинський Аержавний меАичний університет”, м. Чернівці, Україна.

Годованець О. І., А-р меА. наук, Аоцент каф. хірургічної та Аитячої стоматології, ВАНЗ “Буковинський Аержавний меАичний університет", м. Чернівці, Україна.

Годованець О. С., канА. меА. наук, асистент каф. педіатрії, неонатології та перинатальної меАицини, ВАНЗ “Буковинський Аержавний медичний університет”, м. Чернівці, Україна. Ковтун А. І., канА. меА. наук, Аоцент каф. анестезіології та реаніматології, ВАНЗ “Буковинський Аержавний меАичний університет", м. Чернівці, Україна.

\section{Сведения об авторах:}

Безрук В. В., канА. МеА. наук, Аоцент каф. педиатрии, неонатологии и перинатальной меАицины, ВГУЗ “Буковинский государственный медицинский университет", г. Черновцы, Украина.

Безрук Т. А., канА. меА. наук, Аоцент каф. внутренней меАицины и инфекционных болезней, ВГУЗ “Буковинский государственный меАицинский университет”, г. Черновцы, Украина.

Бабий Е. Р., преподаватель каф. иностранного языка, ВГУЗ “Буковинский государственный меАицинский университет”, г. Черновцы, Украина.

Сокольник С. А., А-р меА. наук, Аоцент каф. Аетской хирургии и отоларингологии, ВГУЗ “Буковинский госуАарственный медицинский университет", г. Черновцы, Украина. Шеремет М. И., канА. меА. наук, Аоцент каф. хирургии № 1, ВГУЗ “Буковинский государственный меАицинский университет", г. Черновцы, Украина.

Максимюк В. В., Аоктор меА. наук, профессор каф. хирургии № 1, ВГУЗ “Буковинский госуАарственный меАицинский университет", г. Черновцы, Украина.

ГоАованец О. И., А-р меА. наук, Аоцент каф. хирургической и Аетской стоматологии, ВГУЗ “Буковинский госуАарственный медицинский университет", г. Черновцы,

Украина.

Годованец А. С., канА. меА. наук, ассистент каф. педиатрии, неонатологии и перинатальной меАицины, ВГУЗ “Буковинский государственный меАицинский университет", г. Черновцы, Украина.
Ковтун А. И., канА. меА. наук, Аоцент каф. анестезиологии и реаниматологии, ВГУЗ “Буковинский государственный меАицинский университет”, г. Черновцы, Украина.

Конфлікт інтересів: віАсутній.

Conflicts of Interest: authors have no conflict of interest to declare.

Надійшло Ао редакції / Received: 02.06.2017

Після Аоопрацювання / Revised: 26.06.2017

Прийнято Ао Аруку / Accepted: 07.07.2017 